NBER WORKING PAPER SERIES

\title{
EXPORTING RAISES PRODUCTIVITY IN SUB-SAHARAN AFRICAN MANUFACTURING PLANTS
}

\author{
Johannes Van Biesebroeck \\ Working Paper 10020 \\ http://www.nber.org/papers/w10020 \\ NATIONAL BUREAU OF ECONOMIC RESEARCH \\ 1050 Massachusetts Avenue \\ Cambridge, MA 02138 \\ October 2003
}

I would like to thank Marcel Fafchamps for his help to get me access to the data. Thanks also to Frank Wolak, Lanier Benkard, Peter Reiss, Bruce Blonigen and participants at the 2002 NBER URC-ITI conference for comments on a previous version. Jim Tybout and an anonymous referee provided many useful suggestions. Financial support from the Littlefield Fellowship and the K.U. Leuven, where much of the work was carried out, is gratefully acknowledged. The views expressed herein are those of the authors and are not necessarily those of the National Bureau of Economic Research.

(C)2003 by Johannes Van Biesbroeck. All rights reserved. Short sections of text, not to exceed two paragraphs, may be quoted without explicit permission provided that full credit, including $(\mathrm{C}$ notice, is given to the source. 
Exporting Raises Productivity in Sub-Saharan African Manufacturing Plants

Johannes Van Biesebroeck

NBER Working Paper No. 10020

October 2003

JEL No. F14, O12, O33

\begin{abstract}
Proponents of trade liberalization argue that it will force firms to produce closer to the production possibility frontier and that the frontier will move out faster. In particular, plants that export will achieve a higher productivity level. However intuitive the argument, empirical evidence is meager. This hypothesis is examined by calculating the effect of export status on productivity for a panel of manufacturing plants in nine African countries. The results indicate that exporters in these countries are more productive, replicating a similar finding for developed countries. More importantly, exporters increase their productivity advantage after entry into the export market. While the first finding can be explained by selection---only the most productive firms engage in exporting---the latter cannot. The results are robust when unobserved productivity differences and self-selection into the export market are controlled for using different econometric methods. Scale economies are shown to be an important channel for the productivity advance. Credit constraints and contract enforcement problems prevent plants that only produce for the domestic market to fully exploit scale economies.

Johannes Van Biesebroeck

Department of Economics

University of Toronto

150 St. George Street

Toronto, ON M5S 3G7

and NBER

jovb@chass.utoronto.ca
\end{abstract}




\section{Trade and productivity}

It is a well established fact that plants that face foreign competition or have to satisfy demanding foreign customers are forced to adapt. Previous studies have invariably found exporters to differ substantially from nonexporters and I confirm that finding for plants in sub-Saharan Africa. While most authors have explained the differences by self-selection - only the most productive plants choose to start exporting - I find evidence for learning-by-exporting as well. Even though exporters are more productive than other plants before they start selling abroad, they manage to increase this productivity advantage following their entry into the export market. Exposure to foreign competition or interaction with foreign clients seems to confer some benefits. More formally, the production function depends positively on lagged export status and the effect remains after controlling for the endogenous nature of the export participation decision. I establish and show the robustness of this finding using different econometric methodologies, which yield qualitatively the same and quantitatively very similar results. It is important to note that each methodology favored the self-selection over the learning-byexporting explanation for the positive correlation between productivity and export status when applied to data from other countries.

Opening up to trade is often advocated as a way of stimulating the economy, especially in developing countries. It is an integral part of most IMF and World Bank structural reform programs. Some authors have studied the competitive effects of increased import penetration. For example, Krishna and Mitra (1998) and Tybout and Westbrook (1995) demonstrate that increased competition from imports lowers the price-cost margin. The coarse industry classification in the African data set I use, makes it impossible to identify plants that face competition from increased import penetration. Other authors have emphasized the posi- 
tive effect on aggregate productivity from resource reallocation following trade liberalization. Pavcnik (2002) presents evidence of this process for Chile. Bernard and Jensen (1999b) show for the United States that the reallocation of output share to more productive exporters improves aggregate productivity. Moreover, increased foreign competition leads to closures of less productive plants or induces plants to shift industry, with similar aggregate productivity effects, see Bernard, Jensen, and Schott (2002). To make a convincing case for such effects, one needs to observe the universe of plants, which I don’t.

Instead, I investigate the link between trade openness and productivity by looking at productivity differences for exporters over nonexporters. The example of export-led growth in East Asia underscores the potential for economic development through trade. Plants can benefit from their exporting activities if they learn about and adopt international best practice production methods, receive feedback from international clients and competitors, or benefit from other knowledge spillovers or externalities. Theoretical models by Krugman (1979) and Jovanovic and Lach (1991) incorporate such mechanisms. Alternatively, plants can improve their product offerings by interacting with foreign clients. Fafchamps, El Hamine, and Zeufack (2002) find evidence for this type of market learning in Morocco.

The countries and plants that I study are introduced in Section 2, where I also show that the simple correlation between productivity and export status holds in Africa, at all levels of aggregation. In Section 3, I confirm the widely established fact that exporters differ in important ways from nonexporters. They pay higher wages, operate at a higher scale, produce with more capital, and have higher productivity. The differences are remarkably similar to those reported for other countries. An important point of departure from previous studies is the widening of the gaps after plants enter the export market. This is illustrated by focusing on different points of a plant's export cycle and on growth rates pre and post export market 
entry.

Section 4 contains a more thorough investigation of the central question of the paper: Is the productivity advantage of exporters already established before plants enter the export market or is it increased further post-entry? Using a variety of econometric methods and data from several countries, Bernard and Jensen (1999a), Isgut (2001), Clerides, Lach, and Tybout (1998), and Delgado, Farinas, and Ruano (2002) concluded in favor of the self-selection and against the learning-by-exporting hypothesis. Only the most productive firms are able to compete internationally or have a sufficient cost advantage to overcome transportation costs. Exporters are more productive than nonexporters, not because there are any benefits associated with export activities, but they are simply more productive from the outset. Only a few studies - Kraay (1999), Girma, Greenaway, and Kneller (2002), and Bigsten et al. (2000a)— reach the opposite conclusion. Aw, Chung, and Roberts (2000) find evidence supporting learning-by-exporting in Taiwan, but not in South Korea. I review the different methodologies and the arguments supporting causality conclusions with the corresponding results for the African plants in Section 4.

For African exporters, the evidence points to the learning mechanism as partial explanation. Three different methodologies that concluded in favor of the alternative hypothesis (selfselection by exporters) for other countries and one new approach are used to support this conclusion. In Section 3, the time dimension of the panel is exploited to demonstrate that the differences between exporters and nonexporters widen after entry into the export market. A positive effect of lagged export status on productivity remains after controlling for self-selection and the endogeneity of productivity in the firm's input choices. This is established using instrumental variables, in Section 4.1, by jointly estimating the model of export participation developed in Roberts and Tybout (1997) with the production function, in Section 4.2, and 
using semi-parametric techniques drawing on work by Olley and Pakes (1996), in Section 4.3.

If there is one place one can expect firms to benefit from foreign activities, it is sub-Saharan Africa. The domestic market in all countries is small and foreign sales are a prerequisite to fully exploit scale economies. In Section 5 , I show that approximately $50 \%$ of the productivity premium attributed to exporters results from the higher scale of operation. Nonexporters have more difficulties exploiting scale economies because of widespread contractual problems and lack of credit. Domestic clients frequently postpone or default on payments. Sales to foreign clients or to multinational companies are less likely to generate such problems. Finally, the production technology employed in most African firms is lagging best practice considerably, providing ample scope for productivity improvements through imitation and adoption of foreign technology. Tests for a structural break in the sample supports the conclusion that exporters produce with a different technology than nonexporters.

\section{Countries, plants and exports in Africa}

Literature: The evidence on links between productivity and export status in Africa is relatively meager. Given the amount of protection that still exists and the high dispersion of productivity, the potential benefits of liberalization could be substantial. A few studies investigated trade effects on productivity at the plant-level data. For Cote d'Ivoire, Harrison (1994) finds that foreign-owned plants improve productivity following trade liberalization, while the effects on domestic plants are negative, but insignificant. Clerides, Lach, and Tybout (1998) do not find any impact of lagged export status on costs for Morocco. They conclude that the correlation between export status and productivity is caused by self-selection. For Cameroon, Ghana, Kenya, and Zimbabwe, Bigsten et al. (2000a) find positive effects of exporting on 
productivity and on productivity growth even after accounting for self-selection and firm heterogeneity. Kraay (1999) pioneered the methodology and found a positive effect of lagged exports on productivity for Chinese firms as well. Given that these are the only two studies to find evidence for learning-by-exporting, a robustness check is warranted. ${ }^{1}$

Countries: The sub-Saharan African countries I study are Burundi, Cameroon, Cote d'Ivoire, Ethiopia, Ghana, Kenya, Tanzania, Zambia, and Zimbabwe. All nine are low-income countries with a level of development varying from a GDP per capita of $\$ 446$ in Ethiopia (in current PPP in 1995) to $\$ 2195$ in Zimbabwe. Some summary statistics on the countries are in Table A.1 in the Appendix. Value added per employee in industry is substantially higher, even converted using actual exchange rates. ${ }^{2}$ The share of manufacturing in GDP is relatively small in each country, but it exceeds employment in the sector by a large margin. A fair estimate is that manufacturing workers are 2 to 3 times more productive than the average worker.

The share of manufacturing output that is exported ranges from $6 \%$ in Burundi to $60 \%$ in Cote d'Ivoire, averaging 29\% across countries. Most trade is overseas, as trade flows within the region are small. Europe is an important trading partner for all countries, while Japan, the United States and the Middle East are important for some countries. The last column in Table A.1 shows that the share of manufactured products in total exports averages $23 \%$. Only in Burundi and Zambia is it smaller than the manufacturing share in GDP. It is true, nevertheless, that exports are very concentrated. In all countries but Zimbabwe, one agriculture or mining product accounts for more than $50 \%$ of all exports. Given that half of all gross fixed domestic investment is made up of imported capital goods, it is vital for these countries to diversify

\footnotetext{
${ }^{1}$ Tybout (2000) raises some concerns regarding their approach, see footnote 56. Another concern is that they force all industries in all countries to operate with the same production technology. The data for this paper includes their plants, but adds plants from five additional countries. A recent working paper by Girma, Greenaway, and Kneller (2002) also finds evidence for the learning hypothesis in the U.K. using a matching estimator.

${ }^{2}$ Comparable employment statistics are only available for industry (which also includes mining and utilities).
} 
the sources of foreign exchange revenues. ${ }^{3}$ The obvious solution is to expand manufacturing exports. Over the last two decades this has been happening most successfully in Zambia, Cameroon, and Zimbabwe.

Another indication of the importance of manufacturing exports - and the subject of the remainder of the analysis - is the positive correlation between productivity and export market activity. In Table 1, this is shown to hold at each level of aggregation. Countries, industries, or plants that are more prone to exporting also have a higher level of labor productivity. Of course, this merely establishes a correlation and does not say anything about causality.

Plants: The sample of manufacturing plants is constructed from firm surveys, carried out between 1992 and 1996. In each country approximately 200 firms were interviewed in three consecutive years. ${ }^{4}$ The data collection was coordinated by the Regional Program on Enterprise Development at the World Bank. Firms were sampled from four broadly defined manufacturing sectors: food, textile and clothing, wood and furniture, metal and equipment. The sampling was stratified by plant-size to give each manufacturing employee equal probability to be included. For more information on the plants and the sampling scheme, see Van Biesebroeck (2002). Total value added for the plants included in the sample accounts for almost $40 \%$ of manufacturing GDP in the nine countries combined. ${ }^{5}$

To estimate productivity one needs to observe output and inputs. Most of the analysis uses value added as output, measured as total sales minus raw materials and intermediate

\footnotetext{
${ }^{3}$ In the poorest four countries, the average dependency of domestic investment on imported capital rises to $67 \%$.

${ }^{4}$ In Cote d'Ivoire only two rounds of interviews were completed and in Burundi and Ethiopia only one. Some firms exit the sample and others were added in later rounds to maintain the sample size. Some of the sample attrition is the result of economic factors, e.g. bankruptcy, but an equally important reason for a firm to leave the sample is non-economic. Firms moved or did not want to cooperate anymore. Initially, I ignore entry and exit, but I control for it explicitly when investigating the robustness of the findings.

${ }^{5}$ Because employees at large plants produce more output than employees working at smaller plants, the share of the manufacturing workforce represented by the sampled firms is significantly smaller.
} 
inputs. Labor input is the total number of employees and capital is the replacement value of the plant and equipment at the end of the year. GDP deflators from World Bank (2000) are used to make output, materials, and capital comparable across years. The labor productivity statistics in the last column of Table A.2 are employment weighted averages of plant-level value added per employee. These numbers correspond reasonably well to the aggregate statistics for industry in the second column of Table A.1. The oversampling of larger, more productive plants explains the uniformly higher productivity numbers. The only difference in the relative ranking of countries is the higher aggregate productivity for Zambia-caused by its large copper mining industry — and Cote d'Ivoire - possibly the result of inadequate price deflators following the huge devaluation in the CFA franc. The findings for these plants should reflect the experiences of an important part of the manufacturing sector in the respective countries.

Participation on the export market varies tremendously across countries. Table A.3 contains information on export participation, intensity, and destination for the sample of African manufacturing plants. A number of stylized facts stand out. Participation rises almost monotonically across countries with the level of development of the manufacturing sector. Larger firms, those with more than 250 employees, are much more likely to engage in exporting. The majority of exporters sell less than $20 \%$ of total sales abroad, but large firms tend to export more. A sizeable share of exports, on average $41 \%$, goes to overseas destinations.

The correlations in Table 1 already illustrated that exporters have higher labor productivity and that among exporters the dollar value of exports is also positively correlated with productivity. The differences between exporters and nonexporters are investigated in more detail in the following section. 


\section{Exporters are different}

A number of studies have documented that the differences between exporters and nonexporters go beyond size. Regressing plant characteristics on an export dummy with controls is a popular way to measure those differences. ${ }^{6}$ Bernard and Jensen (1995) were the first to perform this exercise for the United States. Bernard and Wagner (1997) did the same calculations for Germany and Isgut (2001) for Colombia. ${ }^{7}$ Table 2 contains some of their main findings and a column with comparable results for the African plants.

The qualitative findings are identical in each of the four countries (region in the case of Africa). Exporters pay higher wages, produce more output per worker, produce more capitalintensively, sustained by a similarly increased investment rate, and operate at a larger scale. Quantitatively, the coefficients on the export dummy for Africa exceed those of the comparison countries, especially the more developed ones. Most of the coefficients are significant at the 1 percent significance level, even though the African sample is substantially smaller than in the other studies.

The coefficients on the export dummy are also large in an economic sense. Even after controlling for size, exporters pay on average $34 \%$ higher wages. The pay differential is solely due to remuneration of nonproduction workers, as was the case in Germany. ${ }^{8}$ Exporters produce an extra $50 \%$ output per worker, in value added or total sales. The difference can be the result of higher production, but can also stem from higher quality, and more expensive, products. The largest difference between the two types of plants is in the scale of operation.

\footnotetext{
${ }^{6}$ Controls include country specific time dummies, sector and location dummies, and the logarithm of employment to control for size (except in the last two regressions).

${ }^{7}$ Results for the United Kingdom in Girma, Greenaway, and Kneller (2002) are very similar to those for the United States and Germany and are omitted here.

${ }^{8}$ Production and nonproduction workers can only be distinguished in a subset of the sample.
} 
African exporters produce on average $300 \%$ more output and they employ three times as many workers. In the United States and Germany exporters are only twice as large as nonexporters. The enormous size differential is less surprising in less developed countries, where the domestic market for manufactures is small. Most of the estimated size differentials for Colombia are similar to those for the African countries. ${ }^{9}$

The previous results establish that African exporters differ substantially from other plants, with invariably larger differentials than other countries. It makes this sample a promising place to find learning-by-exporting effects. Exploiting the time dimension of the panel data set I can go one step further. If changes in export status are observed, the effect of the export activity can be isolated by comparing productivity before and after. The question is whether the differences between exporters and nonexporters already existed before exporters started exporting and whether differences outlast exit from the export market. Of the 900 plant-years with positive exports (23\% of the sample), 128 observations are plants that just entered the export market. 103 plants stop exporting before the end of the sample period.

I extend the regression results from Table 2 by including a full set of dummies describing the entire export experience of plants. The omitted category are plants that never export. The pre-export dummy distinguishes plants that only start exporting later in the sample from perennial nonexporters. A similar post-export dummy identifies previous exporters after their exit from the export market. Three more dummies are turned on for plants in years that are actively exporting. Plants are classified as "newly entered" or "about to quit" if they start or stop exporting during the sample period. As "continuous exporters" if they export

\footnotetext{
${ }^{9}$ Including the share of sales that is exported as explanatory variable, only produces a significant coefficient in the last two regressions, that measure the size differential (estimates are omitted). Larger plants tend to export a higher share of their output. The small size of the manufacturing sector in African economies makes this almost unavoidable.
} 
throughout.

The results of the regressions are presented concisely in the tree panels of Figure 1. The first thing to note is that each and every line is above the X-axis. ${ }^{10}$ Plants that are active on the export market at any point in time, pay higher salaries, produce more output per worker, and operate with more capital and at larger scale at every point in time, even when they are not exporting. This is consistent with the selection and the learning hypothesis.

The top panel displays the pattern over the export-cycle for the two size variables, sales and employment. Some of the size differential already exists before entry in the export market, it increase slightly with entry, grows tremendously for plants active on the export market for a longer time, and tends to reduce leading up and following exit from the export market. The middle panel shows a similar pattern for the two labor productivity and wage variables. Differences increase while exporting and decrease before and after exit from the export market. The only differences are the larger jumps on initial entry, at least relatively, and firms that have been exporting for a longer time are not distinguishable from new exporters. In the bottom panel, for investment and capital per worker, the initial jump for new exporters is even larger, and the evolution prior to exit is different.

The pattern of gradually increasing differentials when plants start exporting and decreases when they stop are supportive of the learning-by-exporting hypothesis. In particular, for every characteristic considered the difference between active exporters and nonexporters is larger than the differences prior to entry on the export market. In addition, differentials decrease prior to exit from the export market and decrease further (except for capital) post-exit. Few differences are significant, but the pattern is very consistent. Even though many differences

\footnotetext{
${ }^{10}$ The full regression results are in Table B.1 in the Appendix. All coefficients are significantly different from zero, except for three dummies in the investment per worker regression.
} 
are large in an economic sense, a longer or larger sample would be needed to find stronger results.

Equality of the coefficients can be tested pairwise or jointly, see Table B.1. From the tests I can conclude that (a) exporters always differ from perennial nonexporters; (b) continuous exporters are larger than any other group of plants; (c) intermittent exporters have significantly lower labor productivity than continuous exporters before or after their export spells, but hardly lower productivity when they are actively exporting (p-values of 0.22 and 0.28 ); (d) plants primarily increase their capital intensity at the start of export spells.

An alternative strategy is to look at correlations between growth rates and export status. While plants might self-select into the export market based on their productivity level, this is much less likely for productivity growth. This intuition is borne out by the data. First, I regress the growth rates on a dummy indicating whether the plant is ever an exporter. Most coefficients in the first row of Table 3 are positive, but only the value added per worker regression reveals a significant effect. Over their entire export-cycle, exporters do not enjoy consistently higher growth rates than perennial nonexporters. The results are very different when I regress the same growth rates on a dummy for current export activity. In this case, every single coefficient is positive. The effects are very large and highly significant for the labor productivity and size variables. The higher growth rates are not simply firm fixed-effects, given the results in the first row, but are associated with actual export activity.

Including two dummies, one for current and one for past or future export activity, confirms this finding. All coefficients in the last row of Table 3 are negative. Exporters that are currently not active on the export market have lower growth rates than perennial nonexporters. When they are actively exporting the differences are again positive (except for wage growth) and very large, between $3.5 \%$ and $16.3 \%$. Exporters are able to improve productivity, capital 
intensity and size, but only when they are actively exporting, not ex ante or ex post. ${ }^{11}$ I interpret this as further corroborating evidence on the learning-by-exporting hypothesis: only during export spells do plants grow faster.

Given that the goal is to establish a link between productivity and exporting, one would like to go beyond labor productivity. Exporters produce more output per worker, but to some extent this is simply the result of capital deepening. Often the analysis proceeds in two steps. First, productivity is estimated using index numbers (TFP) or econometrically. Subsequently, productivity estimates are regressed on a set of dummy variables, characterizing the export history of a plant. Bernard and Jensen (1999a) and Aw, Chung, and Roberts (2000) adopt this approach with TFP estimates for the United States, Taiwan, and South Korea. They find that the productivity gap between exporters and nonexporters opens up almost entirely in the years prior to entry in the export market. The gap hardly increases after entry. They conclude in favor of the selection and against the learning hypothesis.

TFP has the advantage that no estimation is required, but for the African plants a number of necessary assumptions are likely to be violated. For a subset of the African sample, Söderbom and Teal (2000) illustrate that firms of different sizes face different factor prices and they doubt that factor markets are competitive. Van Biesebroeck (2002) shows that returns to scale are increasing and significantly different from unity. Using Monte Carlo simulations, Van Biesebroeck (2003) illustrates that TFP is less robust to measurement error than econometric productivity estimates, which is an additional concern for the African data set.

Estimating productivity econometrically is one solution, but the endogeneity of export status will still cause trouble. If exporting improves productivity, it allows plants to produce more output from the same inputs, shifting the production frontier out. In the two-step

\footnotetext{
${ }^{11}$ I did not include results with separate pre and post export dummies, because few coefficients are significant.
} 
approach, output is first regressed on inputs, from which a productivity measure is calculated. If export status is correlated with inputs, which was clearly shown to be the case in the previous section, omitting the export dummy from the production function regression yields inconsistent input coefficient and productivity estimates. The straightforward solution is to fold the two steps into one and include the export dummy directly in the production function. ${ }^{12}$

I estimate the following production function

$$
Q_{j t}=A_{j t} L_{j t}^{\alpha_{l c}} K_{j t}^{\alpha_{k c}} \quad \text { with } A_{j t}=e^{\alpha_{x} E X_{j t-\tau}+\omega_{c i t}+\omega_{j t}+\epsilon_{j t}}
$$

The productivity term $A_{j t}$, is a function of export activity $\left(E X_{j t}\right)$, aggregate productivity growth for the country-industry $\left(\omega_{\text {cit }}\right)$, unobserved plant-level productivity $\left(\omega_{j t}\right)$, and random measurement error or a transitory productivity shock $\left(\epsilon_{i t}\right)$. While $\omega_{j t}$ is known to the plant and it conditions its input choices or export decision on it, this is not the case for $\epsilon_{j t}$. The input coefficients vary across country, but I only report the average estimates. ${ }^{13}$ For the moment, I estimate equation (1) using random effects, allowing for correlation of unobserved productivity over time within units, but not controlling for correlation with input or export choices. In the next section, I will control explicitly for both endogeneity problems.

Results in the first and third column of Table 4 confirm the findings from Table 2 . In the full sample of nine countries, exporters are on average $28 \%$ more productive. Limiting the sample to plants that are interviewed at least twice (only those are included when endogeneity problems are controlled for in the next section), this rises to a $37 \%$ productivity advantage.

\footnotetext{
${ }^{12}$ Aitken and Harrison (1999) follow the same approach to estimate productivity effects of FDI. Clerides, Lach, and Tybout (1998) avoid the estimation of productivity altogether, using observable cost data, and look for a link between average variable costs and export status.

${ }^{13}$ Estimating the production function with input coefficients that also vary by industry did not yield any significant differences (results are omitted).
} 
These percentages overstate the learning-by-exporting effect for several reasons. The export dummy picks up the self-selection effect, because export participation is endogenously determined. Using lagged exports partially remedies this effect and it reduces the productivity advantages by a third to $22 \%$, in the fifth column. To the extent that export participation is correlated over time, this is only a partial fix. One mechanism that generates such persistency is the existence of sunk costs of exporting, see for example Roberts and Tybout (1997). Alternative solutions are considered in the next section.

The dependency of input choices on productivity might contribute to the upward bias in the export coefficient. Under fairly general assumptions, the labor coefficient will be affected more severely and be biased upward with a corresponding downward bias in the capital coefficient, see Olley and Pakes (1996). Given that exporters are more capital-intensive, it is likely to induce an overestimate of the export effect. Three different solutions are proposed in the next section. One of the methods I use, GMM-SYS, relies on two lags, which forces me to drop plants from Cote d'Ivoire as well. For comparability, I included the estimates for six countries in the last column. Lagged export status is still associated with higher productivity levels, $18 \%$ higher in this case.

Including a full set of dummies characterizing the entire export history of plants generates results very similar to those in Figure 1. Productivity of future exporters already exceeds that of nonexporters by a large margin even before they enter the export market, evidence of self-selection. When exporting starts, the difference increases and it is even larger for plants that have been exporting for a longer time, evidence of learning-by-exporting. Leading up to exit from the export market productivity decreases and this continues after the actual exit. As before, few difference are statistically significant, but the pattern is remarkably similar.

The before-after identification strategy provides evidence supporting both the self-selection 
and learning-by-exporting hypothesis. Future exporters are already more productive, operate with more capital, and are larger in size than nonexporters before they start exporting. This is not the end of the story. Comparing exporters during export spells and in years that they do not export, consistently shows higher productivity levels and higher productivity growth associated with the export activity. Using a similar identification strategy, Bernard and Jensen (1999a) only found evidence pointing towards self-selection in the United States and likewise for Aw, Chung, and Roberts (2000) for South Korea.

Clerides, Lach, and Tybout (1998) used two different identification strategies - exogeneity assumptions on lagged inputs and augmenting the model of production with an export participation equation - to find support only for the self-selection hypothesis. In the next section, I adapt both of their methods and a fourth semiparametric approach, to control for unobserved productivity differences and self-selection. This last method has the added benefit of controlling for exit. For the African plants, all methods support the existence of learning-by-exporting effects.

\section{Learning-by-exporting controlling for self-selection}

\subsection{Instrumental variables: GMM-SYS}

Because the export status of firms is not randomly assigned, one should control for it. If conditioning on observables is sufficient to control for selection, it suffices to regress productivity on $E X_{j t-1}$ include those variables, as in Aw, Chung, and Roberts (2000), Bernard and Jensen (1999a), and Bigsten et al. (2000a), or simply include those variables directly in 
the production function (1). ${ }^{14}$ Alternatively, one can control for selection using instrumental variables, which requires weaker assumptions. Only the instruments need to be independent of the unobserved productivity, while before the export status itself had to be conditionally independent. Similar arguments are used to control for the simultaneity of input choices and unobserved productivity.

Clerides, Lach, and Tybout (1998) estimate a variant of equation (1) using a generalized method of moments estimator. They do not control for the potential simultaneity of (lagged) exports and unobserved productivity, but note that the variance of the unobserved productivity was estimated very small in their maximum likelihood estimation. Neglecting self-selection is likely to bias their findings towards finding learning effects. The results they obtain using the GMM estimator are hardly more supportive of the learning-by-exporting hypothesis than the ML results in Colombia, but they find some positive effects for a number of Moroccan industries.

I estimate equation (1) using the GMM-SYS estimator of Blundell and Bond (1998). Unobserved productivity is assumed to evolve according to an autoregressive process

$$
\omega_{j t}=\rho \omega_{j t-1}+\epsilon_{j t} . \quad|\rho|<1
$$

In its dynamic representation the production function in logarithms becomes

$$
q_{j t}=\alpha_{x}\left(E X_{j t-1}-\rho E X_{j t-2}\right)+\alpha_{l c}\left(l_{j t}-\rho l_{j t-1}\right)+\alpha_{k c}\left(k_{j t}-\rho k_{j t-1}\right)+\rho q_{j t-1}
$$

\footnotetext{
${ }^{14}$ The results in Bigsten et al. (2000a) still suffer from the two-stage omitted variable problem mentioned earlier, because they first estimate productivity econometrically. Girma, Greenaway, and Kneller (2002) use the same idea in a matching estimator with data for the U.K. and they find some support for the learning hypothesis.
} 


$$
+\underbrace{\left(\alpha_{c i t}-\rho \alpha_{c i t-1}\right)}_{\alpha_{c i t}^{*}}+\underbrace{\left(\epsilon_{j t}-\rho \epsilon_{j t-1}\right)}_{\epsilon_{j t}^{*}} .
$$

The GMM-SYS approach simultaneously estimates equation (2) in levels and in first differences. Twice lagged input and output variables figure as instruments in the differenced equation and lagged first differences are the instruments for the level equation. Estimating both equations controls for the persistent part of unobserved productivity, without throwing away the information contained in the levels. Because there are two lags, only data for six countries can be used. In Table 5, I report results with and without enforcing the coefficient restrictions in the first and fourth columns, respectively. Tests resoundingly reject the coefficient restrictions on lagged coefficients and I will focus on the unrestricted results.

Exogeneity of the export status can be tested with a Durbin-Hausman specification test. The p-value for the test-statistic is 0.05 and I reject the exogeneity assumption. Four additional variables are used as instruments for lagged export status: the location of the firm, ethnicity of the owner, foreign ownership, and state ownership. The intuition is that firms located in the capital will be more prone to exporting simply because transport infrastructure is better developed. The ethnicity of the owner influences the extent of domestic and foreign contacts. If the owner belongs to a domestic minority or speaks a foreign language, the firm is more likely to export. Firms with some foreign ownership are, ceteris paribus, also more likely to export. The Sargan test for overidentifying restrictions is reported to asses the validity of the instruments, assuming at least one variable is a proper instrument. When the coefficient restrictions are not enforced, in the fourth column, the validity of the instrument set is not rejected. ${ }^{15}$ All coefficient estimates and tests are reported in the first and fourth column of

\footnotetext{
${ }^{15}$ With the restrictions enforced, the p-value for the Sargan test is much lower, but it does not decline when export status (in addition to inputs) is treated as endogenous. The lagged variables, not the instruments for export status, seem to be the weak instruments.
} 
Table 5 below.

\subsection{Modeling export participation: MLE}

The estimation method outlined in the previous section is fairly flexible, but because of the twice lagged instruments it can only use a limited sample. The result is a positive, but only marginally significant coefficient estimate on lagged export status. Another way of controlling for the endogeneity of export market status is to model the participation decision explicitly and jointly estimate it with the production function (1). This approach is more demanding in terms of economic assumptions (and programming effort), but generates more precise estimates. Clerides, Lach, and Tybout (1998) pioneered this approach to evaluate the impact of exporting on firms in Colombia and Morocco. They jointly estimate an average variable cost equation and a selection rule for entry into the export market. Unobserved effects that influence exporting and productivity are incorporated and allowed to be correlated across equations. They find that lagged export status is not significant in the cost function, while lagged costs do predict export status. They conclude in favor of the self-selection hypothesis and against learning-by-exporting.

Kraay (1999) and Bigsten et al. (2000a) estimate a similar model for China and four African countries. ${ }^{16}$ While Clerides, Lach, and Tybout (1998) use observable cost data as dependent variable in the first equation, these studies use an econometric estimate of productivity as dependent variable. This risks introducing omitted variable bias, as discussed on page 13 .

\footnotetext{
${ }^{16}$ Bigsten et al. (2000a) uses some of the same data as this paper, but limits the sample to only four countries and uses a different approach to calculate productivity. Their implementation makes the restrictive assumption that all countries share the same production function. Another point of difference is that they assume a discrete distribution for the unobservable effects variables and estimate the three points of support, instead of integrating out continuous random variables.
} 
The system of equations I estimate is given by

$$
\begin{aligned}
q_{j t} & =\sum_{\tau=1}^{T}\left(\alpha_{q \tau} q_{j t-\tau}+\alpha_{x \tau} E X_{j t-\tau}\right)+\alpha_{l c} l_{j t}+\alpha_{k c} k_{j t}+\omega_{1 j}+\epsilon_{1 j t} \\
E X_{j t} & = \begin{cases}1 & \text { if } \sum_{\tau=1}^{T}\left(\beta_{q \tau} \tilde{q}_{j t-\tau}+\beta_{x \tau} E X_{j t-\tau}\right)+\sum_{z=1}^{4} \gamma_{z} Z_{j t}^{z}+\omega_{2 j}+\epsilon_{2 j t} \geq 0 \\
0 & \text { otherwise. }\end{cases}
\end{aligned}
$$

The input coefficients in the production function vary by country $(c=1 \ldots 7)$. The four dummy variables $Z^{1}-Z^{4}$ are the exogenous determinants of export status that were used as instruments in the previous section: location in the capital city, foreign ownership, ethnic owner, state ownership. The right-hand side variable in the probit equation $\tilde{q}_{j t-1}$ (and $\tilde{q}_{j t-2}$ ) is lagged productivity, calculated by rearranging equation (2), deducting all observable righthand side variables from $q_{j t-1}$, and substituting in equation (3). Country-year and industry are added to both equations. The short duration of the panel limits the number of lags I can include to two $(T \leq 2) \cdot{ }^{17}$ The remaining estimation issues are handled as in Clerides, Lach, and Tybout (1998). Both error terms $\epsilon_{1}$ and $\epsilon_{2}$ are assumed to be i.i.d. normally distributed. The unobserved productivity terms $\omega_{1}$ and $\omega_{2}$ are integrated out using Gaussian quadrature, allowing for correlation between both terms. Lagged equations are added to the system to solve the initial values problem. They contain only the exogenous variables in the system and nuisance parameters. For the full likelihood function, see Clerides, Lach, and Tybout (1996). Results are in the second and fifth column of Table 5 .

\footnotetext{
${ }^{17}$ Using two lags the sample is the same as for the GMM-SYS estimation. Including only a single lag in output (productivity) and export status, allows the use of plants from Cote d'Ivoire as well.
} 


\subsection{Semiparametric estimation: OP}

Finally, I adapt the semiparametric estimator developed by Olley and Pakes (1996) to control for unobserved productivity and export status. A benefit of this approach is the explicit control for exit from the sample that is assumed to happen when productivity falls below a threshold. In particular, Olley and Pakes (1996) argue that plants with more capital are likely to wither greater reductions in productivity, making the exit threshold a decreasing function of capital. ${ }^{18}$

Underlying the approach is an investment function, $i_{t}=I_{t}\left(k_{t}, a_{t}, \omega_{t}\right)$ which is monotonically increasing in productivity $(\omega)$ for any given level of capital $(k)$ and age $(a)$. As a result, the investment equation is invertible, producing an expression for productivity as an unknown function of investment, capital, and age. In the first estimation step, this expression is substituted in the production function and the coefficient on labor (or any other variable input coefficient) is recovered using nonparametric techniques, controlling for the dependency on investment, capital, and age. In the second step, the survival probability of a plant is predicted, using a nonparametric probit regression. In the third and final step, coefficients on the state variables - capital and age - are recovered, using semiparametric nonlinear least squares.

For the current application, the investment function and survival probability will depend on export status as well, while the dependency on plant age is ignored. Exporters might choose a different investment level and have a different exit rule, even controlling for capital stock and productivity, because of different market prospects. Hence, I specify $i_{t}=I_{t}^{\prime}\left(k_{t}, E X_{t}, \omega_{t}\right)$ and $\operatorname{Prob}($ exit after period $t)=\operatorname{Prob}\left(\omega_{t+1} \leq \underline{\omega}_{t}\left(k_{t}, i_{t}, E X_{t}\right)\right.$. Given that both relationships conditions on the observable export status, no new derivations are necessary. The investment

\footnotetext{
${ }^{18}$ Imperfections in the capital market or a profit function that is increasing in capital - e.g. a constant returns to scale Cobb-Douglas production function-will produce such a result.
} 
function is still monotonic in productivity even though the functional relationship is likely to differ for exporters and nonexporters. The nonparametric inversion is simply made export status specific. ${ }^{19}$ The only difference with the Olley-Pakes estimator is to replace age by export status in each step and to recover the coefficient on lagged export status in the third step. ${ }^{20}$ Even though export status does not evolve deterministically as is the case for age, it remains quite general to assume that it evolves according to a Markov process as a function of lagged productivity and lagged export status, which is what the theory requires. Results with this approach are in the third and sixth column of Table 5.

\section{$4.4 \quad$ Results}

The results using each of the three estimation methods are in Table 5 . In the first three columns, only one lag of export status and (where applicable) the dependent variable is included. In the last three columns, two lags are included. For the GMM estimator, two lags are always necessary, but in the first column the coefficient restrictions are enforced. Country-year interactions and industry and location dummies are included as controls in each equation, but not reported. Coefficients on labor and capital vary by countries, as before, but only the average estimate and standard error are reported.

The coefficient estimates of virtually all export dummies are positive, although only significantly different from zero if a single lag is included. Engaging in exporting appears to shifts the production function out by $20 \%$ to $38 \%$, depending on the estimation method. The

\footnotetext{
${ }^{19}$ Even plants that change export status do not pose a problem, as the investment function will be increasing in export status, see the evidence in Table 2, while at the same time plants with higher productivity are more likely to start exporting, from the evidence on self-selection. Both effects reinforce each other and will not change the monotonic relationship between investment and productivity.

${ }^{20}$ Note that this adjusted Olley-Pakes method estimates the coefficient of interest, the one on lagged export status, in the third step. The nonparametric inversions in the first two steps control for current export status.
} 
sign and magnitude of the export coefficient estimates are plausible and supportive of the learning-by-exporting hypothesis. Test for the null hypothesis of no effect of exporting on productivity, after controlling for self-selection, are rejected in the first three and the fifth columns. $^{21}$

Comparing the first column in Table 5 with the last two columns in Table 4 produces the counterintuitive result that the coefficient on the export dummy jumps when export status is treated as endogenous and instrumented. This is generally the case in the literature on treatment effects that uses instruments for identification. If the effect of treatment - engaging in exporting - varies across plants, the point estimate of the treatment dummy will depend on which observations drive the instrumental variables identification. ${ }^{22}$ The positive correlation between exporting and productivity, in Table 4, is partly explained by self-selection of more productive plants. Some firms enter the export market because of high initial productivity, without deriving any benefit from that activity. The IV identification strategy measures the productivity effect of exporting from firms that enter the export market for different reasons. Some firms export simply because they are located close to necessary transport infrastructure or because the owner has family or business partners abroad, even though their productivity level by itself would never warrant entry into the export market. These firms did not have high initial productivity, but face the same foreign competition. They stand more of a change

\footnotetext{
${ }^{21} \mathrm{~A}$ longer sample could potentially provide stronger results. The only country for which more data (five years in total) is available is Ghana. Unfortunately, this is also the country with the third lowest export participation rate (second lowest for large firms), second lowest foreign sales intensity, and lowest overseas sales of all countries. As a result, one would expect to find the lowest learning-by-exporting effects in Ghana. In addition, the sample is relatively small in the fourth and fifth year. 120 Ghanaian firms are observed in each of the first three waves, while only 44 extra firms are observed at least three times in the five year sample period. Each of the four estimation methods produce results similar to those in Table 4 and 5 . The lagged export dummy is 0.23 (t-statistic of 1.33) using the random effect panel data estimator; $0.26(0.40)$ with the GMM-SYS estimator; 0.29 (1.20) with the MLE; and 0.27 (1.02) with the Olley-Pakes estimator.

${ }^{22}$ In a similar econometric context, Card (2001) illustrates that when returns to schooling are estimated with IV, individuals with low schooling or (unobserved) ability generally drive the identification. These individuals are likely to have higher returns to schooling, making the estimated return with IV invariably exceed the OLS estimate.
} 
of benefiting from the foreign exposure and it is not implausible to find a higher coefficient estimate for the export dummy. The instruments are constant over time for most plants and fail to distinguish between the once and twice lagged effects in the fourth column. Standard errors are substantially larger if the restrictions are not enforced.

The second and fifth column in Table 5 contain the results of joint estimation of the production function and export participation decision with maximum likelihood. The latter results are in Appendix B. Even though many coefficients are still not estimated as precisely as one would hope, most are now significantly different from zero at the $5 \%$ significance level. The results lend support to both the self-selection and learning-by-exporting hypothesis. The positive coefficients on lagged productivity $\left(\tilde{q_{t-j}}\right)$ in the export participation equation, see Table B.2 in the Appendix, confirm that more productive plants are more likely to enter the export market. The significant and large coefficients on lagged export status in the same equation indicate sunk costs of entry. Past export activity is one of the best predictors for current export activity. The ethnicity and nationality of the firm owner have most predictive power for the export status.

The positive coefficients on the lagged export dummies in the production function point to the presence of learning effects. Previous activity on the export market raises current output, even controlling for the selection effect. The effects are slightly larger than the GMM estimate and become even stronger when two lags of export history are included. It takes time for positive effects to materialize. Firms that only exported last period are able to produce $21 \%$ more output. If firms were exporting for both of the previous periods, the productivity advancement increases to $55 \%$, which is significantly higher. If these effects seem (implausibly) large, one should keep in mind that the productivity dispersion in Africa 
exceeds similar measures for the U .S. ${ }^{23}$ The results in Table 5 also assume that all firmsexporters and nonexporters - use a production technology with the same scale economies, which are constant over the entire output range. In the next section, I investigate whether exporters produce on a different point on a more flexible production frontier or with a different technology altogether.

The result with the semiparametric estimator, in the third and sixth column, confirm the findings. As expected, the labor coefficient is estimated smaller than with the random effects estimator. The export coefficient drops slightly from the random effects estimate, $20 \%$ versus $22 \%$ previously, but remains in the same ballpark. It is still estimated significantly different from zero, although only when a single lag is included. Controlling for exit from the sample did not have much impact on the results. Correlation between productivity and exit does not seem to be a serious problem. Recall that the sample is not a census and that there are many causes for firms to drop out.

All three identification strategies that failed to find learning-by-exporting effects in other countries point towards firms benefiting from previous export activity in Africa. A fourth semiparametric method that controls for sample attrition and allows for a very flexible evolution of unobserved productivity differences gives basically the same results, supportive of the learning hypothesis. A natural next step is to question what is causing the higher productivity that exporters enjoy. I investigate two potential benefits, returns to scale and better contract enforceability. Both effects are likely to interact.

\footnotetext{
${ }^{23}$ Van Biesebroeck (2002) shows that the productivity ratio the 80 th to the 20 th percentile firm in the different African countries of the sample ranges from 4.1 in Zimbabwe to over 9 in Ethiopia, Ghana, and Zambia. The comparable ratio for U.S. manufacturing firms was 2.75 in 1987.
} 


\section{Sources of productivity advantage}

\section{$5.1 \quad$ Returns to Scale}

The most intuitive and straightforward benefit for exporters is the ability to sell in a larger market. The domestic market in each sample country is relatively small and returns to scale are estimated to be increasing. In a survey of manufacturing in developing countries, Tybout (2000) mentions that the potential scale economies in developing countries are smaller than commonly expected. He cites, based on studies for Asia, Latin America and Northern Africa, returns to scale between 1.05 and 1.10, which are slightly lower than the 1.10 to 1.15 estimates I obtain in Africa, see Table 4. He is right to argue that such mild economies of scale are unlikely to be the cause of the stalled development process, but profit maximizing firms can be expected to try to exploit them, for example by starting to export.

It was shown before that exporters are clearly larger and that the size gap increases with entry into the export market. The size of the productivity advantage attributed to exporters depends crucially on the assumption regarding returns to scale. If the production function is estimated with constant returns to scale (CRS) enforced, the productivity advantage of exporters increases substantially. The first two columns in Table 6 shows an export advantage of $45 \%$ under CRS, relative to $22 \%$ under VRS. Without economies of scale, the export dummy absorbs some of the size effect. Approximately half of the productivity advantage of exporters can be attributed to the realization of scale economies.

One might object to an interpretation of scale economies realized by exporters as a productivity advantage. A more flexible specification of the production technology should allow scale economies to vary by plant size. This is the case for a translog production function. Estimation results are in the third column of Table 6. Country-specific quadratic and in- 
teraction terms are included, but not reported. Inputs are normalized by country to have mean zero, which gives the linear coefficients the same interpretation as for the Cobb-Douglas technology. Average scale economies for the sample are still estimated to be increasing, at 1.13, but evaluating the function separately for the average exporter and nonexporter shows a clear difference. Returns to scale are estimated higher for nonexporters, 1.17 versus 1.08, and the difference is statistically different at a $1 \%$ significance level. Exporters choose to operate higher up on the production frontier, where remaining scale economies are diminished.

One could go one step further and argue that the two groups of plants do not operate with the same technology. Exporters differ in many respects from nonexporters. They have a higher capital-labor ratio, invest more frequent, have higher value added as a percentage of sales, introduce new technology more frequent, and are more likely to have a formal training program for employees. ${ }^{24}$ Adoption of production technology could provide another channel for exporters in developing countries to improve productivity. For example, Barro and Salai-Martin (1997) built a model where countries copy new technologies from more advanced trading partners, leading to convergence in income between countries.

I estimate the production function separately for exporters and nonexporters and test for a structural break in the sample between the two categories. The last two columns of Table 6 contain these results. Exporters do not only differ from nonexporters in productivity level, but also in input elasticities, or returns to scale. Returns to scale are not significantly different from one for exporters, indicating that these firms have exhausted all scale economies. Nonexporters, on the other hand, produce at a point on the production function with significantly increasing returns to scale. Allowing different coefficients in the production function highlights the differences between the two groups of plants. It confirms the higher capital intensity (the

\footnotetext{
${ }^{24}$ See Van Biesebroeck (2002) for evidence from the same data set.
} 
capital coefficient is $27 \%$ of the sum of both inputs, versus $17 \%$ for nonexporters) and productivity growth $(+12 \%$ versus $-2 \%)$ for exporters. The Chow test for structural break, which assumes equal variation of the residual for both types, decidedly rejects that exporters and nonexporters share the same technology. The $\chi^{2}$-distributed test statistic is 2.86 , while the critical value for a $1 \%$ significance level is 1.94 . The Wald test, which allows for different variations, confirms this result. The F-statistic is 22.08 , while the $1 \%$ critical value is $13.28{ }^{25}$

\subsection{Trade credit and contract defaults}

The results in Section 3 revealed that exporters are substantially larger and that their size advantage was largely established while exporting, not before entry on the export market. Many of the firms in the sample report to be operating at a lower scale than they would like. When asked directly, $16 \%$ of the owners or managers mention that insufficient demand is the principal limit to expansion, second only to credit availability. Almost a third of the owners lists it as one of the three most important problems. It is a particularly acute problem for the group of smallest enterprises if they do not export, while small exporters hardly mention it. ${ }^{26}$ The largest problem by far, for these firms, is the limited availability of formal credit, see the first line in Table 7. Domestically oriented firms are more likely to report being growth and/or credit constraint. ${ }^{27}$

Some evidence indicates that both problems are related. In order to increase sales, firms often extend trade credit to their clients. The statistics in Table 7 list the outstanding amounts

\footnotetext{
${ }^{25}$ Interestingly, if the sample is similarly split between large (more than 100 employees) and small firms, the only significant difference is the estimated returns too scale, while the relative importance of capital and labor as well as the average productivity growth are nearly identical.

${ }^{26}$ Lack of demand is one of the main problems for $34 \%$ of nonexporters that employ less than 50 workers, against only $10 \%$ for similarly-sized exporters.

${ }^{27}$ In contrast, the third most important problem, inappropriate infrastructure, is equally important for firms of different size and independent of export orientation.
} 
of credit at the time of interview as a percentage of total sales. Exporters, especially smaller ones, award substantially more trade credit and also receive slightly more. For formal credit, the big distinction is between small and large firms, while export status hardly matters. To underscore the importance of trade credit, I list the importance of various forms of credit as percentage of sales, as well as the (weighted) average credit period, in Table B.3 in the Appendix. While the total amount of trade credit is of the same order of magnitude as the amount of formal credit, it turns over much more rapidly. The risks involved are correspondingly greater.

More than $75 \%$ of all firms give trade credit, but the difficulty enforcing contracts in Africa makes this a particularly risky expansion strategy. Payments are often late, leading to disputes and renegotiations. ${ }^{28}$ Almost two thirds of all firms report having had late or nonpayment problems with domestic clients in the last year. The large number of problems reported, between 4 and 12 a year on average, make clear that it is a widespread phenomena. Sales to foreign firms, on the other hand, are significantly less likely to lead to disputes. Exporters report that only $8 \%$ of all client related payment problems are with foreign firms, even though they make up more than $30 \%$ of the sales in the sample. ${ }^{29}$ When a problem with a foreign firm arises it is three out of four times the first, and possible also the last, business contact. In contrast, when payment problems arise with domestic firms, the two firms already had an established business relationship in five out of six cases. It is not surprising then that exporters extend trade credit more easily to their clients. Most importantly, small exporters use trade credit liberally, aiding expansion and realizing scale economies. A bill of lading is one institution that facilitates this practice by exporters. Once the goods are shipped off to

\footnotetext{
${ }^{28}$ See Bigsten et al. (2000b).

${ }^{29}$ Statistically, payment by foreign firms turns out to be as reliable as payment by family members.
} 
the client, the seller's bank arranges payment directly with the buyer's bank, taking over the exporter's contract risk.

One can wonder to what extent these contractual considerations weaken the self-selection or learning effects, by reducing the correlation between productivity and export status. To address this explicitly, I reestimate the model with production function and export participation decision from Section 4.2, including three extra lagged variables as determinants of the export decision. ${ }^{30}$ Results for a limited number of coefficients are in the "endogenous export participation" columns of Table 8. Firms are slightly more likely to start exporting if one or two years ago they experienced contractual problems with clients, reported to be constraint by lack of demand, or extended a lot of trade credit. The contractual variables are estimated imprecisely, especially in the equation with only one export lag. With two lags, all variables enter with positive sign, as expected, albeit still not significantly different from zero. The effect of lagged export status is slightly reduced, but still large and positive. The coefficient drops only slightly from 0.35 to 0.29 , when only one export lag is included. There seems to be some selection into the export market based on these "problem" variables, but not a strong effect. The self-selection effect based on unobserved productivity remains robust after controlling for contractual problems.

Because exporting helps firms to realize scale economies, there is an effect over and beyond the self-selection. They might start exporting to reduce their exposure to client defaults, but the higher scale of operation will show up as productivity gains if returns to scale are constant across firms or if exporters produce at a different point on the same production frontier, as the translog estimates in the third column of Table 6 suggest. If exporters operate with a

\footnotetext{
${ }^{30}$ The contractual problem variables are only available in the first year. Therefore, I limit the sample to firms that participated in the first wave.
} 
different technology, self-selection can have further beneficial effects of inducing firms to adopt a technology with higher productivity growth.

Assuming that exporting solves the contractual, lack of demand, and excessive trade credit problem, one can verify whether firms that start exporting for exogenous reasons also suffered from the same contractual problems. If this is the case, some of the effects attributed to learning-by-exporting may fundamentally come from foreign sales solving domestic contracting problems, rather than shifting out the (technological) production frontier. A two step approach addresses this question. First, export status is predicted using the exogenous variables from the GMM and MLE approaches in Sections 4.1 and 4.2, including country and industry dummies. This isolates the exogenous tendency for firms to start exporting and abstract from any self-selection effects. In the second stage, the predicted export probability is regressed on the three contractual variables. If these coefficients have positive signs, it means that firms that started exporting for exogenous reasons, the very firms that drive identification of the learning-by-exporting effects in the GMM and MLE approaches, suffered from the three contractual problems. If exporting adequately solves those, the learning effects might simply pick up the resolution of the contractual problems.

Results in the last two columns of Table 8 confirm that previous contractual problems, lack of demand, or large trade credit given, are positively related to future export status. ${ }^{31}$ At least some of the learning effects might indicate resolution of contractual problems, rather than higher production efficiency.

\footnotetext{
${ }^{31}$ The usual procedure in a cross-section would be to run the reverse regressions and see whether contract problems and the two other variables can be predicted by the exogenous component of the export status. Running these separate regressions also yielded positive coefficients. I do not report these results as they involve predicting past variables using future behavior, which are hard to interpret.
} 


\section{Conclusions}

Exporters of manufacturers in sub-Saharan Africa have a higher level of productivity than nonexporters. This replicates similar findings for a number of other countries. In contrast with the other studies, the productivity gap in Africa cannot solely be attributed to self-selection of more productive firms into the export market. Exporters increase their productivity advantage after they start exporting. They not only have a higher productivity level, but also a higher rate of productivity growth. The productivity advantage for exporters remains after controlling for the endogeneity of the export decision using instrumental variables or explicitly estimating the export participation decision jointly with the production function. A fourth semiparametric method that controls in addition for sample selection supports the same conclusion. All of this points to the presence of some learning-by-exporting effects.

To explain the productivity gap, returns to scale are particularly important. Exporters have exhausted scale economies, while nonexporters are producing at a point on the production function with significant increasing returns to scale. I can reject the hypothesis that both types of firms produce with the same technology, which is consistent with the acquisition of more advanced technologies by exporters from interacting with foreign clients and competitors. In particular, exporting can solve the perceived lack of demand that many firms face. Domestic expansion is limited by the lack of formal. The higher risks associated with trade creditaccounts-collectable problems with domestic firms are widespread-makes extending credit to clients a risky expansion strategy. Exporting can provide a solution by providing access to a more reliable client base and through the specific institutions that deal with credit risks associated with foreign trade. This effect has not been documented before and warrants further investigation. 


\section{References}

Aitken, B. J. and A. E. Harrison (1999, June). Do Domestic Firms Benefit from Direct Foreign Investment? Evidence from Venezuela. American Economic Review 89 (3), 60518.

Aw, B. Y., S. Chung, and M. J. Roberts (2000, January). Productivity and Turnover in the Export Market: Micro-level Evidence from the Republic of Korea and Taiwan (China). World Bank Economic Review 14(1), 65-90.

Barro, R. J. and X. Sala-i-Martin (1997, March). Technological Diffusion, Convergence, and Growth. Journal of Economic Growth 2(1), 1-26.

Bernard, A., J. B. Jensen, and P. Schott (2002). Survival of the Best Fit: Competition from Low Wage Countries and the (Uneven) Growth of US Manufacturing Plants. mimeo.

Bernard, A. B. and J. B. Jensen (1995). Exporters, Jobs, and Wages in U.S. Manufacturing, 1976-1987. Brookings Papers on Economic Activity, Microeconomics, 67-119. Washington DC.

Bernard, A. B. and J. B. Jensen (1999a). Exceptional Exporter Performance: Cause, Effect, or Both? Journal of International Economics 47(1), 1-26.

Bernard, A. B. and J. B. Jensen (1999b). Exporting and Productivity. NBER Working Paper No. 7135 .

Bernard, A. B. and J. Wagner (1997). Exports and Success in German Manufacturing. Weltwirtschaftliches Archiv 133(1), 134-57.

Bigsten, A., P. Collier, S. Dercon, M. Fafchamps, B. Gauthier, J. W. Gunning, A. Isaksson, A. Oduro, R. Oostendorp, C. Pattillo, M. Söderbom, F. Teal, and A. Zeufack (2000a). Exports and Firm-level Efficiency in African Manufacturing. WPS 16.

Bigsten, A., P. Collier, S. Dercon, M. Fafchamps, B. Gauthier, J. W. Gunning, A. Isaksson, A. Oduro, R. Oostendorp, C. Pattillo, M. Söderbom, F. Teal, and A. Zeufack (2000b, April). Contract Flexibility and Dispute Resolution in African Manufacturing. Journal of Development Studies 36(4), 1-17.

Blundell, R. W. and S. R. Bond (1998). Initial Conditions and Moment Restrictions in Dynamic Panel Data Models. Journal of Econometrics 87, 115-43.

Card, D. (2001, September). Estimating the Return to Schooling: Progress on Some Persistent Econometric Problems. Econometrica 69(5), 1127-60.

Clerides, S. K., S. Lach, and J. R. Tybout (1996, August). Is Learning By Exporting Important? Micro-Dynamic Evidence from Colombia, Mexico, and Morocco. NBER Working Paper No. 5715.

Clerides, S. K., S. Lach, and J. R. Tybout (1998). Is Learning By Exporting Important? Micro-Dynamic Evidence from Colombia, Mexico, and Morocco. Quarterly Journal of Economics 113(3), 903-947.

Delgado, M. A., J. C. Farinas, and S. Ruano (2002). Firm Productivity and Export Markets: a Non-parametric Approach. Journal of International Economics 57, 397-422. 
Fafchamps, M., S. El Hamine, and A. Zeufack (2002). Learning to Export: Evidence from Moroccan Manufacturing. mimeo.

Girma, S., D. Greenaway, and R. Kneller (2002). Does Exporting Lead to Better Performance? A Microeconometric Analysis of Matched Firms. mimeo.

Harrison, A. E. (1994, February). Productivity, Imperfect Competition, and Trade Reform. Theory and Evidence. Journal of International Economics 36(1-2), 53-73.

Isgut, A. E. (2001, June). What's Different about Exporters? Evidence from Colombian Manufacturing. Journal of Development Studies 37(5), 57-82.

Jovanovic, B. and S. Lach (1991, June). The Diffusion of Technology and Inequality among Nations. NBER Working paper No. 3732.

Kraay, A. (1999). Exportations et Performances Economiques: Etude d'un Panel d'Entreprises Chinoises. Revue d'Economie Du Developpement 0(1-2), 183-207.

Krishna, P. and D. Mitra (1998). Trade Liberalization, Market Discipline and Productivity Growth: New Evidence from India. Journal of Development Economics 56, 447-62.

Krugman, P. (1979, April). A Model of Innovation, Technology Transfer, and the World Distribution of Income. Journal of Political Economy 87(2), 253-66.

Olley, G. S. and A. Pakes (1996). "The Dynamics of Productivity in the Telecommunications Equipment Industry". Econometrica 64(6), 1263-97.

Pavcnik, N. (2002, January). Trade Liberalization, Exit, and Productivity Improvement: Evidence from Chilean Plants. Review of Economic Studies 69(1), 245-76.

Roberts, M. and J. Tybout (1997, September). The Decision to Export in Colombia: An Empirical Model of Entry with Sunk Costs. American Economic Review 87, 545-64.

Söderbom, M. and F. Teal (2000). Skills, Investment, and Exports from Manufacturing Firms in Africa. Journal of Development Studies 37(2), 13-43.

Tybout, J. R. (2000, March). Manufacturing Firms in Developing Countries: How Well Do They Do, and Why? Journal of Economic Literature 28, 11-44.

Tybout, J. R. and M. D. Westbrook (1995). Trade Liberalization and the Dimensions of Efficiency Change in Mexican Manufacturing Industries. Journal of International Economics 39, 53-78.

Van Biesebroeck, J. (2002, April). Comparing the Size and Productivity Distribution of Manufacturing Plants in sub-Saharan Africa and the United States. mimeo, University of Toronto.

Van Biesebroeck, J. (2003, July). Robustness of Productivity Estimates. mimeo, University of Toronto.

World Bank (2000). African Development Indicators. computer file. 
Figure 1: The pattern for the evolution of difference between several characteristics.

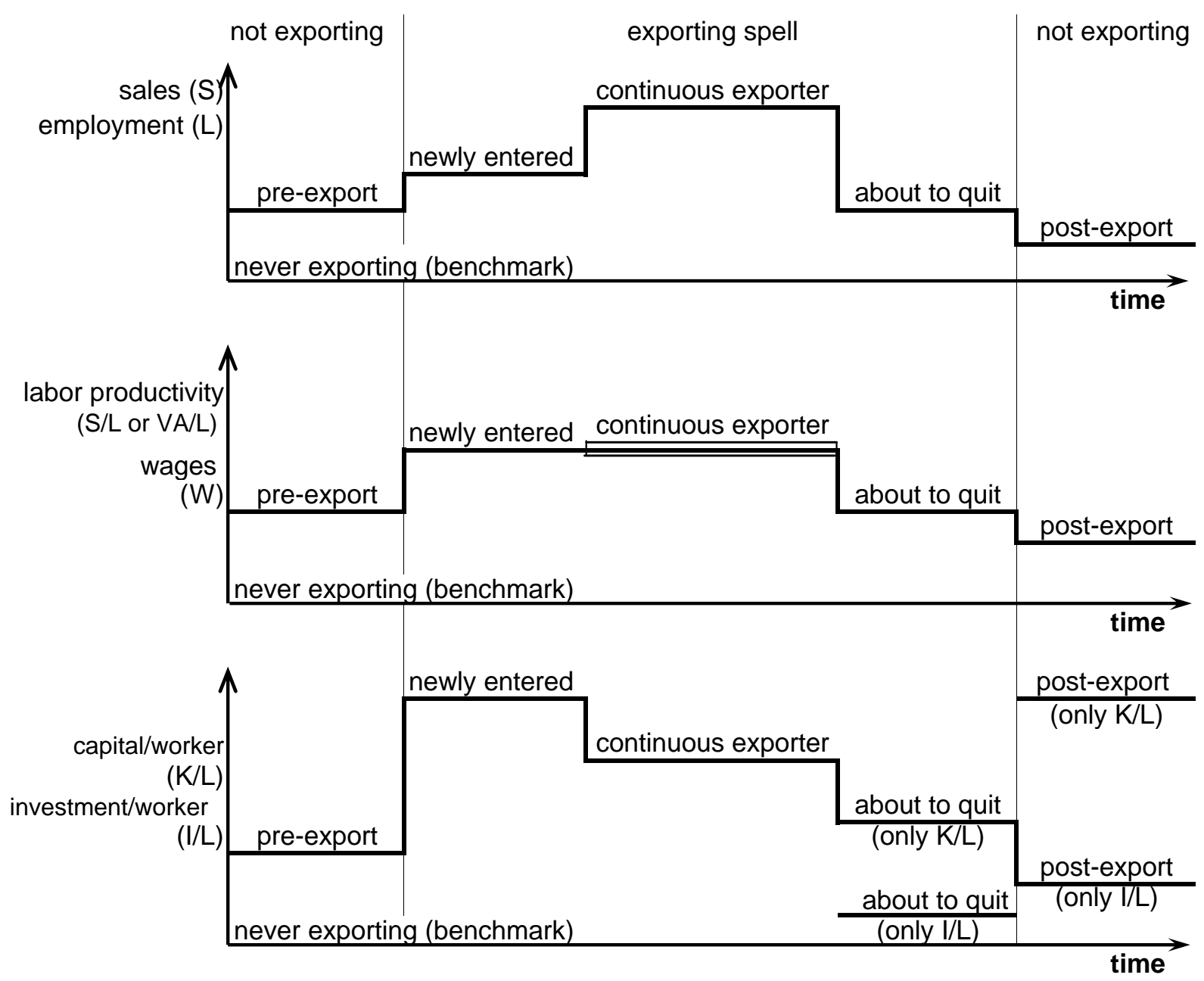


Table 1: Export status is correlated with productivity level

\begin{tabular}{|c|c|c|c|c|}
\hline Correlation between LP and ... & $\begin{array}{l}\text { unit of } \\
\text { observation }\end{array}$ & $\begin{array}{c}\text { number of } \\
\text { observations }\end{array}$ & $\begin{array}{c}\text { partial } \\
\text { correlation }\end{array}$ & (p-value) \\
\hline aggregate export share $^{a}$ & country & 9 & 0.434 & $(0.244)$ \\
\hline export share in manufacturing & country & 7 & 0.523 & $(0.229)$ \\
\hline export share by (country-)industry & industry & 92 & 0.356 & $(0.001)$ \\
\hline export participation & plant $^{b}$ & 3772 & 0.256 & $(0.000)$ \\
\hline value of exports for exporters & plant $^{b}$ & 1054 & 0.293 & $(0.000)$ \\
\hline
\end{tabular}

Source: World Bank (2000);

${ }^{a} \mathrm{GDP} /$ capita (instead of LP); ${ }^{b}$ Excludes plants in the highest and lowest productivity percentile.

Table 2: OLS regressions of plant characteristics on export status

\begin{tabular}{lcccc}
\hline \hline & $\begin{array}{c}\text { Sub-Saharan Africa } \\
(1)\end{array}$ & $\begin{array}{c}\text { United States } \\
(2)\end{array}$ & $\begin{array}{c}\text { Germany } \\
(3)\end{array}$ & $\begin{array}{c}\text { Colombia } \\
(4)\end{array}$ \\
\hline Average wage $\left(\frac{W}{L}\right)$ & $0.341^{* *}$ & $0.093^{* *}$ & 0.017 & $0.173^{* *}$ \\
Production wage & -0.016 & $0.074^{* *}$ & -0.018 & $0.112^{* *}$ \\
Nonproduction wage & $0.288^{* *}$ & $0.054^{* *}$ & $0.023^{*}$ & $0.141^{* *}$ \\
Shipments per worker $\left(\frac{S}{L}\right)$ & $0.527^{* *}$ & $0.149^{* *}$ & $0.194^{* *}$ & $0.463^{* *}$ \\
Value added per worker $\left(\frac{V A}{L}\right)$ & $0.560^{* *}$ & $0.158^{* *}$ & $0.216^{* *}$ & $0.461^{* *}$ \\
Capital per worker $\left(\frac{K}{L}\right)$ & $0.501^{* *}$ & $0.093^{* *}$ & $0.122^{* *}$ & $0.486^{* *}$ \\
Investment per worker $\left(\frac{I}{L}\right)$ & $0.498^{* *}$ & $0.036^{* *}$ & $0.076^{*}$ & $0.481^{* *}$ \\
Nonproduction/total workers & 0.006 & $0.124^{* *}$ & $0.040^{* *}$ & $0.044^{* *}$ \\
Shipments $(S)$ & $3.124^{* *}$ & $1.100^{* *}$ & $0.957^{* *}$ & $1.237^{* *}$ \\
Employment $(L)$ & $2.126^{* *}$ & $0.936^{* *}$ & $0.717^{* *}$ & $1.972^{* *}$ \\
Number of observations $(\max )$ & 3,800 & 190,000 & 4,200 & 70,000 \\
\hline \hline
\end{tabular}

(1) Statistics are the coefficient estimates of an export dummy in a plant-level regression, controlling for country-years, industry, location and log employment (except in shipment and employment regressions).

(2) Bernard and Jensen (1995) Table 7; (3) Bernard and Wagner (1997) Table 3; (4) Isgut (2001) Table 5. ${ }^{*}$ and ${ }^{* *}$ denote significance at the 5 percent and 1 percent significance level. 
Table 3: OLS regressions of growth rates on dummies for export status.

\begin{tabular}{lccccccc}
\hline \hline & $\frac{W}{L}$ & $\frac{S}{L}$ & $\frac{V A}{L}$ & $\frac{K}{L}$ & $\frac{I}{L}$ & $S$ & $L$ \\
\hline Ever an exporter & -0.022 & 0.058 & $0.102^{*}$ & 0.016 & 0.037 & 0.064 & 0.016 \\
Current exporter & 0.007 & $0.098^{* *}$ & $0.174^{* *}$ & 0.108 & 0.075 & $0.114^{* *}$ & $0.040^{*}$ \\
Current exporter & -0.003 & $0.092^{* *}$ & $0.163^{* *}$ & 0.085 & 0.061 & $0.105^{* *}$ & $0.035^{*}$ \\
Future or past exporter & -0.085 & -0.054 & -0.096 & $-0.207^{*}$ & -0.094 & -0.072 & -0.046 \\
\hline Observations & 1754 & 1933 & 1933 & 1933 & 603 & 1933 & 1933 \\
\hline \hline
\end{tabular}

Regressions as in Table 2, with growth rates as dependent variables, controlling for employment growth in the first five columns. The first two rows are separate regressions, while in the last two rows, both dummies are included together. $\quad * *$ : significant at the $1 \%$ level, *: at the $5 \%$ level.

Table 4: Exporters are more productive

\begin{tabular}{|c|c|c|c|c|c|c|}
\hline & \multicolumn{2}{|c|}{$\begin{array}{l}\text { All observations } \\
\text { (nine countries) }\end{array}$} & \multicolumn{3}{|c|}{$\begin{array}{l}\text { Interviewed twice or more } \\
\quad(\text { seven countries })\end{array}$} & \multirow{2}{*}{$\begin{array}{l}\text { Three interviews } \\
\text { (six countries) } \\
(6)\end{array}$} \\
\hline & $(1)$ & $(2)$ & $(3)$ & $(4)$ & $(5)$ & \\
\hline Current export status & $\begin{array}{l}0.281 \\
(.056)\end{array}$ & $\begin{array}{l}0.618 \\
(.095)\end{array}$ & $\begin{array}{l}0.373 \\
(.075)\end{array}$ & $\begin{array}{l}0.618 \\
(.115)\end{array}$ & & \\
\hline Lagged export status & & & & & $\begin{array}{l}0.220 \\
(.073)\end{array}$ & $\begin{array}{l}0.178 \\
(.077)\end{array}$ \\
\hline Pre-export & & $\begin{array}{l}0.508 \\
(.118)\end{array}$ & & $\begin{array}{l}0.528 \\
(.167)\end{array}$ & & \\
\hline Newly entered & & $\begin{array}{l}0.552 \\
(.119)\end{array}$ & & $\begin{array}{l}0.574 \\
(.125)\end{array}$ & & \\
\hline About to exit & & $\begin{array}{l}0.320 \\
(.129)\end{array}$ & & $\begin{array}{l}0.083 \\
(.189)\end{array}$ & & \\
\hline Post-export & & $\begin{array}{l}0.296 \\
(.127)\end{array}$ & & $\begin{array}{l}0.219 \\
(.134)\end{array}$ & & \\
\hline Labor (average) & $\begin{array}{l}0.925 \\
(.069)\end{array}$ & $\begin{array}{l}0.894 \\
(.070)\end{array}$ & $\begin{array}{l}0.900 \\
(.079)\end{array}$ & $\begin{array}{l}0.871 \\
(.079)\end{array}$ & $\begin{array}{l}0.913 \\
(.079)\end{array}$ & $\begin{array}{l}0.970 \\
(.075)\end{array}$ \\
\hline Capital (average) & $\begin{array}{l}0.170 \\
(.037)\end{array}$ & $\begin{array}{l}0.167 \\
(.037)\end{array}$ & $\begin{array}{l}0.223 \\
(.043)\end{array}$ & $\begin{array}{l}0.220 \\
(.043)\end{array}$ & $\begin{array}{l}0.228 \\
(.043)\end{array}$ & $\begin{array}{l}0.177 \\
(.038)\end{array}$ \\
\hline Observations & 3851 & 3851 & 3170 & 3170 & 1935 & 1410 \\
\hline Firms & 1922 & 1922 & 1230 & 1230 & 1230 & 705 \\
\hline $\mathrm{R}^{2}$ & 0.842 & 0.842 & 0.848 & 0.848 & 0.847 & 0.832 \\
\hline
\end{tabular}

Cobb-Douglas production function estimated with random effects, allowing for country-specific input coefficients. Country-year, industry, and location dummies are included as controls. 
Table 5: Production function estimates, controlling for self-selection and unobserved productivity.

\begin{tabular}{lccc|ccc}
\hline \hline & GMM & MLE & SP & GMM & MLE & SP \\
& $(1)$ & $(2)$ & $(3)$ & $(4)$ & $(2)$ & $(3)$ \\
\hline Labor (average) & 1.067 & 0.246 & 0.729 & 0.212 & 0.255 & 0.782 \\
& $(0.10)$ & $(0.06)$ & $(0.06)$ & $(0.20)$ & $(0.06)$ & $(0.08)$ \\
Capital (average) & 0.054 & 0.026 & 0.095 & 0.033 & 0.036 & 0.018 \\
& $(0.02)$ & $(0.03)$ & $(0.05)$ & $(0.01)$ & $(0.03)$ & $(0.07)$ \\
$q_{j t-1}$ & 0.611 & 0.351 & & 0.613 & 0.735 & \\
& $(0.06)$ & $(0.03)$ & & $(0.21)$ & $(0.03)$ & \\
$q_{j t-2}$ & & & & -0.011 & 0.447 & \\
& & & & $(0.02)$ & $(0.04)$ & \\
$E X_{j t-1}$ & 0.285 & 0.379 & 0.196 & 0.255 & 0.210 & 0.211 \\
& $(0.15)$ & $(0.15)$ & $(0.10)$ & $(0.26)$ & $(0.17)$ & $(0.18)$ \\
& & & & -0.014 & 0.334 & 0.026 \\
& & & & $(0.14)$ & $(0.17)$ & $(0.16)$ \\
\hline Observations & 705 & 1930 & 1935 & 705 & 705 & 705 \\
\hline For all tests the p-values are reported: & & & & \\
$\mathrm{H}_{0}: E X_{t-i}=0, \quad \forall i$ & 0.07 & 0.01 & 0.02 & 0.51 & 0.01 & 0.25 \\
$\mathrm{H}_{0}: E X_{t-i}$ exogenous & 0.04 & & & 0.05 & & \\
Sargan test & 0.01 & & & 0.20 & & \\
\hline \hline
\end{tabular}

Production function (1) estimated by (1) GMM system estimator enforcing constraints;

(4) GMM-SYS not enforcing constraints, see Section 4.1; (2) Maximum likelihood, see Section 4.2;

(3) Semiparametric three-step estimator, see Section 4.3. 
Table 6: Testing for differences in technology and scale economies.

\begin{tabular}{|c|c|c|c|c|c|}
\hline & \multicolumn{2}{|c|}{ all firms } & \multirow{2}{*}{$\begin{array}{c}\text { all firms } \\
\text { Translog-VRS }\end{array}$} & exporter & nonexporter \\
\hline & CD-VRS & CD-CRS & & \multicolumn{2}{|c|}{ Translog-VRS } \\
\hline \multirow{2}{*}{$E X_{t-1}$} & 0.219 & 0.451 & 0.195 & & \\
\hline & $(.074)$ & $(.068)$ & $(.074)$ & & \\
\hline \multirow[t]{2}{*}{ Labor (average) } & 0.913 & 0.750 & 0.898 & 0.738 & 0.969 \\
\hline & $(.079)$ & - & $(.084)$ & $(.202)$ & $(.116)$ \\
\hline \multirow[t]{2}{*}{ Capital (average) } & 0.228 & 0.250 & 0.236 & 0.270 & 0.202 \\
\hline & $(.043)$ & $(.042)$ & $(.046)$ & $(.115)$ & $(.063)$ \\
\hline \multirow[t]{2}{*}{ Time trend (average) } & -0.010 & -0.025 & -0.002 & 0.121 & -0.019 \\
\hline & $(.076)$ & $(.078)$ & $(.076)$ & $(.221)$ & $(.017)$ \\
\hline Quadratic terms & No & No & Yes & Yes & Yes \\
\hline RTS for exporters & 1.14 & 1.00 & 1.08 & 1.01 & \\
\hline RTS for nonexporters & 1.14 & 1.00 & 1.17 & & 1.17 \\
\hline Number of observations & 1933 & 1933 & 1933 & 499 & 1434 \\
\hline
\end{tabular}

Estimation is with random effects as in Table 4 with country, industry, and location dummies. Both the linear and quadratic (not reported) coefficients on inputs and time vary by country.

Table 7: Contracts and credit.

\begin{tabular}{|c|c|c|c|c|}
\hline & \multicolumn{2}{|c|}{ exporters } & \multicolumn{2}{|c|}{ nonexporters } \\
\hline & small $^{a}$ & large & small & large \\
\hline One of main problems is lack of credit & 0.51 & 0.39 & 0.58 & 0.41 \\
\hline One of main problems is lack of demand & 0.19 & 0.26 & 0.30 & 0.28 \\
\hline One of main problems is infrastructure & 0.14 & 0.15 & 0.15 & 0.16 \\
\hline (Number of firms) & $(204)$ & $(696)$ & $(2394)$ & $(557)$ \\
\hline Trade credit received & 0.103 & 0.181 & 0.080 & 0.085 \\
\hline Trade credit given & 0.677 & 0.180 & 0.144 & 0.108 \\
\hline Formal loans received & 0.126 & 0.203 & 0.143 & 0.218 \\
\hline (Number of firms) & $(366)$ & $(534)$ & $(2676)$ & $(275)$ \\
\hline Late or non-payment by a client ${ }^{b}$ & 0.664 & 0.657 & 0.587 & 0.657 \\
\hline Number of non-payments (if any) ${ }^{b}$ & 5 & 12 & 4 & 6 \\
\hline Last problem was with a foreign client & 0.082 & 0.086 & & \\
\hline (Number of firms) & $(135)$ & $(210)$ & $(1147)$ & $(134)$ \\
\hline
\end{tabular}


Table 8: Effect of contractual problems on export status.

\begin{tabular}{lccccc}
\hline \hline & \multicolumn{2}{c}{ Endogenous export participation $^{a}$} & & \multicolumn{2}{c}{ Exogenous exporters $^{b}$} \\
\cline { 2 - 3 } \cline { 5 - 6 } Dependent variable & $E X_{t}$ & $E X_{t}$ & & $\hat{\operatorname{Pr}}\left(E X_{t}=1\right)$ & $\hat{\operatorname{Pr}}\left(E X_{t}=1\right)$ \\
\hline$E X_{t-1}$ & 1.895 & 2.054 & & & \\
$E X_{t-2}$ & $(.368)$ & $(.448)$ & & & \\
& & 0.401 & & & \\
Contractual variables $)$ & $(t-1)$ & $(.230)$ & & $(t-1)$ & $(t-2)$ \\
Contract problem? & -0.150 & 0.047 & & 0.023 & 0.052 \\
& $(.236)$ & $(.220)$ & & $(.011)$ & $(.010)$ \\
Lack of demand? & -0.054 & 0.195 & & 0.029 & 0.025 \\
& $(.181)$ & $(.191)$ & & $(.012)$ & $(.010)$ \\
Trade credit given $(\log )$ & 0.484 & 0.262 & & 0.028 & 0.020 \\
& $(.540)$ & $(.276)$ & & $(.016)$ & $(.013)$ \\
\hline Number of observations & 862 & 692 & & 862 & 692 \\
\hline \hline
\end{tabular}

${ }^{a}$ Export participation jointly estimated with the production function using MLE, as in (2) and (5) of Table 5 and Table B.2, adding the three contractual variables. (Other variables hardly changed and are not reported)

${ }^{b}$ In a first stage (not reported), export status is predicted using the same instruments as in Table 5. In the second stage (results reported), the predicted probability of exporting is regressed on the three variables of interest. 


\section{Appendix A: Summary statistics}

Table A.1: Summary statistics for the nine sub-Saharan countries (1995)

\begin{tabular}{lccccc}
\hline \hline & GDP per capita & VA per employee & manuf. share & \multicolumn{2}{c}{ export share } \\
\cline { 5 - 6 } & $(\mathrm{PPP})$ & in industry $(\mathrm{USD})^{b}$ & in GDP & in manuf. & $\frac{E X_{m}{ }^{c}}{E X_{t o t}}$ \\
\hline Ethiopia & 446 & 1690 & 0.07 & $0.23^{a}$ & $0.30^{c}$ \\
Tanzania & 485 & 983 & 0.07 & 0.21 & 0.16 \\
Burundi & 759 & 2450 & 0.13 & 0.06 & 0.09 \\
Zambia & 936 & 5507 & 0.10 & 0.20 & 0.08 \\
Kenya & 1112 & 1704 & 0.09 & 0.32 & 0.16 \\
Ghana & 1511 & 1089 & 0.06 & $0.20^{d}$ & $0.30^{e}$ \\
Cote d'Ivoire & 1588 & 5915 & 0.16 & 0.60 & 0.36 \\
Cameroon & 1755 & 7904 & 0.10 & 0.21 & 0.14 \\
Zimbabwe & 2195 & 7042 & 0.19 & 0.45 & 0.37 \\
\hline \hline
\end{tabular}

Source: World Bank (2000), ${ }^{a}$ UN International Trade Statistics Yearbook, 1992

Notes: ${ }^{b}$ Industry comprises manufacturing, mining, and utilities;

${ }^{c}$ Share of manufactured goods in total exports; ${ }^{d}$ in GDP; ${ }^{e} 1997$

Table A.2: Summary statistics for the sample of manufacturing plants

\begin{tabular}{llcccc}
\hline \hline & years & $\begin{array}{c}\text { \# of } \\
\text { plants }\end{array}$ & $\begin{array}{c}\text { \# of } \\
\text { observations }\end{array}$ & $\begin{array}{c}\text { coverage } \\
\text { of GDP }\end{array}$ & $\begin{array}{c}\text { LP } \\
\text { (USD) }\end{array}$ \\
\hline Ethiopia & 1996 & 207 & 207 & 0.79 & 5493 \\
Tanzania & $1992,1993,1994$ & 241 & 485 & 0.31 & 3057 \\
Burundi & 1993 & 105 & 105 & 0.65 & 6169 \\
Zambia & $1992,1993,1994$ & 262 & 532 & 0.12 & 5689 \\
Kenya & $1992,1992,1994$ & 267 & 609 & 0.17 & 5993 \\
Ghana & $1991,1992,1993$ & 209 & 497 & 0.14 & 3845 \\
Cote d'Ivoire & 1994,1995 & 188 & 303 & 0.52 & 10930 \\
Cameroon & $1992,1993,1994$ & 234 & 557 & 0.63 & 9627 \\
Zimbabwe & $1992,1993,1994$ & 203 & 556 & 0.26 & 7618 \\
\hline \hline
\end{tabular}

Notes: ${ }^{a}$ Total value added in the first interview year as a percentage of manufacturing GDP.

Table A.3: Trade statistics for the sample of manufacturing plants

\begin{tabular}{|c|c|c|c|c|c|c|}
\hline & \multicolumn{2}{|c|}{ export participation } & \multicolumn{2}{|c|}{ share of sales exported } & \multicolumn{2}{|c|}{ share exported overseas } \\
\hline & all firms & large firms & unweighted & weighted $^{a}$ & unweighted & weighted $^{a}$ \\
\hline Ethiopia & 0.02 & 0.15 & 0.40 & 0.60 & & \\
\hline Tanzania & 0.09 & 0.60 & 0.24 & 0.27 & 0.43 & 0.82 \\
\hline Burundi & 0.17 & 1.00 & 0.28 & 0.37 & & \\
\hline Zambia & 0.09 & 0.48 & 0.19 & 0.24 & 0.22 & 0.38 \\
\hline Kenya & 0.22 & 0.68 & 0.31 & 0.32 & 0.24 & 0.26 \\
\hline Ghana & 0.11 & 0.30 & 0.31 & 0.21 & 0.54 & 0.20 \\
\hline Cote d'Ivoire & 0.44 & 0.87 & 0.54 & 0.49 & 0.53 & 0.57 \\
\hline Cameroon & 0.28 & 0.94 & 0.31 & 0.37 & 0.36 & 0.41 \\
\hline Zimbabwe & 0.49 & 0.86 & 0.20 & 0.17 & 0.27 & 0.22 \\
\hline
\end{tabular}

Notes: ${ }^{a}$ sales weighted, ${ }^{b}$ of total exports 


\section{Appendix B: Additional tables}

Table B.1: OLS regressions with more detail on the export status

\begin{tabular}{lccccccc}
\hline \hline & $\frac{W}{L}$ & $\frac{S}{L}$ & $\frac{V A}{L}$ & $\frac{K}{L}$ & $\frac{I}{L}$ & $S$ & $L$ \\
\hline pre-entry & 0.303 & 0.564 & 0.605 & 0.287 & 0.232 & 2.153 & 1.313 \\
& $(0.10)$ & $(0.11)$ & $(0.12)$ & $(0.17)$ & $(0.27)$ & $(0.18)$ & $(0.12)$ \\
newly entered & 0.364 & 0.617 & 0.675 & 0.623 & 0.800 & 2.277 & 1.377 \\
& $(0.10)$ & $(0.11)$ & $(0.12)$ & $(0.17)$ & $(0.25)$ & $(0.19)$ & $(0.13)$ \\
continuous exporter & 0.390 & 0.608 & 0.632 & 0.557 & 0.531 & 3.631 & 2.494 \\
$(\mathrm{CE})$ & $(0.06)$ & $(0.06)$ & $(0.07)$ & $(0.10)$ & $(0.15)$ & $(0.09)$ & $(0.06)$ \\
about to quit & 0.323 & 0.379 & 0.408 & 0.544 & 0.006 & 1.947 & 1.301 \\
& $(0.11)$ & $(0.13)$ & $(0.14)$ & $(0.19)$ & $(0.33)$ & $(0.21)$ & $(0.14)$ \\
post-exit & 0.284 & 0.367 & 0.282 & 0.691 & 0.296 & 1.865 & 1.239 \\
& $(0.11)$ & $(0.12)$ & $(0.13)$ & $(0.18)$ & $(0.30)$ & $(0.20)$ & $(0.14)$ \\
\hline $\mathrm{H}_{0}: \mathrm{CE}=$ pre & 0.40 & 0.71 & 0.84 & 0.13 & 0.27 & 0.00 & 0.00 \\
$\mathrm{H}_{0}: \mathrm{CE}=$ post & 0.34 & 0.06 & 0.01 & 0.49 & 0.45 & 0.00 & 0.00 \\
$\mathrm{H}_{0}: \mathrm{CE}=$ pre $=$ post & 0.47 & 0.16 & 0.04 & 0.22 & 0.43 & 0.00 & 0.00 \\
$\mathrm{H}_{0}: \mathrm{CE}=$ new $=$ quit & 0.82 & 0.22 & 0.28 & 0.92 & 0.17 & 0.00 & 0.00 \\
$\mathrm{H}_{0}:$ new $=$ pre & 0.65 & 0.73 & 0.68 & 0.14 & 0.11 & 0.59 & 0.68 \\
$\mathrm{H}_{0}:$ quit $=$ post & 0.80 & 0.94 & 0.50 & 0.57 & 0.51 & 0.74 & 0.72 \\
\hline \hline
\end{tabular}

Similar regressions as in Table 2, with more detail on export status.

Statistics for the hypothesis tests are p-values for two sided tests.

I illustrate with the first column how to read Table B.1. Continuous exporters pay 39\% higher salaries than perennial nonexporters, which is statistically significant as the t-statistic is 6.5

$(=0.39 / 0.06)$. In fact, the difference between all groups of plants and nonexporters are significantly different from zero. Plants that start exporting during the sample period already paid 30\% higher salaries before they actually sold anything abroad, which rises to $36 \%$ after exporting starts. The difference between current exporters and plants that will only start exporting later is not significant, as the $\mathrm{p}$-value for the test $\left(\mathrm{H}_{0}: \mathrm{CE}=\right.$ pre) is 0.40 . The difference pre and post export market entry is also not significant, with a p-value of 0.65. Even after exporters exit from the export market they keep paying higher salaries than nonexporters, $28 \%$ higher, which is lower but not significantly different from their competitors that remained active in the export market (the p-value is 0.34 ). The wage gap with nonexporters declines slightly, to $32 \%$, prior to exit from the export market, again an insignificant difference. Testing whether continuous exporters are different from nonexporters that will enter the export market later or have just quit $\left(\mathrm{H}_{0}: \mathrm{CE}=\right.$ pre $=$ post $)$ or from exporters that have just started or will shortly seize $\left(\mathrm{H}_{0}: \mathrm{CE}=\right.$ new $=$ quit $)$, gives negative answers with respective p-values of 0.80 and 0.65 . 
Table B.2: Maximum likelihood estimates of export participation decision

\begin{tabular}{lcc}
\hline \hline \multicolumn{2}{l}{ Dependent variable: exporter $=1$, nonexporter $=0$} \\
\hline capital city & 0.168 & -0.251 \\
& $(0.57)$ & $(0.61)$ \\
state owner & 0.097 & -0.654 \\
& $(1.20)$ & $(1.03)$ \\
ethnic owner & 0.233 & 0.718 \\
& $(0.68)$ & $(0.59)$ \\
foreign owner & 1.312 & 1.693 \\
& $(0.62)$ & $(0.57)$ \\
$\tilde{q}_{j t-1}$ & 0.216 & 0.073 \\
& $(0.24)$ & $(0.29)$ \\
$\tilde{q}_{j t-2}$ & & 0.723 \\
& & $(0.38)$ \\
$E X_{j t-1}$ & 2.855 & 2.664 \\
& $(0.56)$ & $(1.23)$ \\
$E X_{j t-2}$ & & 0.465 \\
& & $(0.74)$ \\
$\mathrm{H}_{0}: E X_{t-\tau}=0, \forall \tau$ & 0.00 & 0.01 \\
$\mathrm{H}_{0}: \tilde{q}_{t-\tau}=0, \forall \tau$ & 0.18 & 0.05 \\
\hline \hline
\end{tabular}

Jointly estimated with production function, columns SP in Table 5.

Table B.3: Importance of trade credit.

\begin{tabular}{|c|c|c|c|}
\hline & \multirow{2}{*}{$\begin{array}{c}\text { amount outstanding } \\
\text { (as \% of sales) }\end{array}$} & \multicolumn{2}{|c|}{ total credit period (days) } \\
\hline & & average $^{a}$ & median \\
\hline Net trade credit & 0.103 & & \\
\hline Net with suppliers & 0.160 & 6.4 & 1 \\
\hline Net with clients & -0.057 & 9.7 & 2 \\
\hline Gross trade credit & 0.296 & & \\
\hline Gross credit extended & 0.200 & 9.8 & 2 \\
\hline Gross credit received & 0.097 & 5.9 & 1 \\
\hline Formal credit & 0.384 & & \\
\hline Loans & 0.155 & 1970 & 1080 \\
\hline Overdrafts & 0.229 & & \\
\hline Informal loans & 0.015 & 315 & 60 \\
\hline Informal borrowing & 0.005 & 153 & 60 \\
\hline
\end{tabular}

${ }^{a}$ weighted by credit amount 